\title{
Phylogenetic positions of three Amorphophallus species natively growing in the Meratus Mountains, South Kalimantan, Indonesia
}

\author{
DINDIN HIDAYATUL MURSYIDIN`, MUHAMMAD ALDY HERNANDA \\ Program of Biology, Faculty of Mathematics and Natural Sciences, University of Lambung Mangkurat. Jl. A. Yani Km. 36, Banjarbaru 70714, South \\ Kalimantan, Indonesia. Tel.: +62-511-4773112, `email: dindinhm@gmail.com
}

Manuscript received: 18 April 2021. Revision accepted: 24 April 2021.

\begin{abstract}
Mursyidin DH, Hernanda MA. 2021. Phylogenetic positions of three Amorphophallus species natively growing in the Meratus Mountains, South Kalimantan, Indonesia. Biodiversitas 22: 2821-2828. Information on genetic diversity and relationships (phylogenetic position) of germplasm is essential for conservation and breeding programs in the future. Here, we focused on determining the genetic diversity and phylogenetic positions of three native Amorphophallus species from the Meratus Mountains, South Kalimantan, Indonesia, using the $r b c \mathrm{~L}$ marker. The results show that this germplasm has a medium level of genetic diversity (0.63). The phylogenetic analyses (NJ, ML, and MP) revealed that Amorphophallus from the region has a unique or specific relationship position. In this case, $A$. muelleri with an accession number of MT818204 and MT818205 are grouping and have close relatedness with A. muelleri previously deposited in GenBank (AF497087.1). Three samples of A. paeoniifolius (MT818202, MT818203, and MT818206) have also clustered with the same species (DQ012500.1; AF497091.1). An interesting result was shown by A. borneensis (MT818211) that demonstrated a close relationship with A. tinekeae (DQ012505.1) in NJ and ML analyses, not with a similar species (DQ012484.1) in MP analysis. Further, a bootstrap analysis on an earlier analysis supported the separation. Thus, this information is valuable in supporting the conservation and breeding programs of this germplasm, both locally and globally.
\end{abstract}

Keywords: Conservation, Genetic diversity, Phylogeny, Plant breeding, Wild species.

Abbreviations: NJ: Neighbor Joining; ML: Maximum Likelihood; MP: Maximum Parsimony.

\section{INTRODUCTION}

Amorphophallus, belonging to the Araceae family, is a large genus with over 200 species reported (Claudel et al. 2017). This genus is distributed mainly in Old World tropical forests, including Asia, Oceania, and Africa (Mekkerdchoo et al. 2016), from close to the coastal line to an altitude up to $900 \mathrm{~m}$ a.s.l. and adapts to low light intensities (Santosa et al. 2017). Amorphophallus exhibits a wide range of agro-ecological adaptation to dry and moist soils. It is abundant under trees shading home gardens, mixed gardens, secondary forests, and agroforestry, as well as open fields (Grob et al. 2002; Santosa et al. 2017). Because of its high abundance, around $70 \%$, Southeast Asia estimated to be the center of diversity of this genus (Claudel et al. 2017).

For a long time ago, several Amorphophallus species have been used as a traditional medicine in several Asian countries, particularly in China and India (Dey et al. 2012, Gao et al. 2017a). Recently, this germplasm has attracted an economic interest, both for food resources and pharmaceutical products worldwide (Mekkerdchoo et al. 2016). Amorphophallus paeoniifolius, known as elephant foot yam or A. campanulatus (syn.), and A. muelleri are the two Amorphophallus examples with these economic values, particularly for commercial glucomannan and other substances, like ceramide (Mekkerdchoo et al. 2016, Zhong et al. 2018).
In general, Amorphophallus shows a high variation morphologically, so that it is very difficult to distinguish each other, especially at intrageneric level (Claudel et al. 2017; Gholave et al. 2017). Nowadays, various DNA markers can be useful to characterize germplasm with close genetic relationships (Terentieva et al. 2020). Of these, chloroplast DNA (cpDNA) or DNA barcode is an excellent marker to study the genetic diversity and relationships of plants because of its conserved gene order, maternal inheritance, and low mutation rate (Gao et al. 2017b). In this study, we have used the $r b c \mathrm{~L}$ region of cpDNA to determine the genetic relationship or phylogenetic position of three wild Amorphophallus species from the Meratus Mountains of South Kalimantan, Indonesia.

Indeed, although $r b c \mathrm{~L}$ provides low resolution compared with other cpDNA markers, particularly matK, it does offer several advantages, including its presence across the plant kingdom, unambiguous alignment, high primer universality, and high sequence quality (Dong et al. 2014). Furthermore, this barcode region is easy to amplify, sequence, and align in most terrestrial plants and provides a useful backbone to the barcode dataset, despite it having only modest discriminatory power (Hollingsworth et al. 2011). Finally, $r b c \mathrm{~L}$ generates high-quality sequence output with easily retrievable across phylogenetically divergent lineages, and it performs well in discrimination tests in combination with other loci (CBOL 2009). 
On the other hand, determination of phylogenetic relationships among wild Amorphophallus species is very urgent to undertaken, mainly for germplasm conservation, evaluation, and utilization in future breeding programs (Gao et al. 2017b). According to Gao et al. (2017a), wild relatives of domesticated plants provide important gene reservoirs for improving commercial cultivars. In recent years, handful of phylogenetic studies have been undertaken on some Amorphophallus species using chloroplast DNA (cpDNA) regions (Gao et al. 2017b; Sedayu et al. 2010). However, the phylogenetic studies of Amorphophallus species in Indonesia, particularly South Kalimantan, have not been well performed, except in Java (Nikmah et al. 2016, Wahyudi et al. 2016), Bali, and Lombok (Kurniawan et al. 2011).

Thus, the objectives of our study were to (i) estimate the genetic diversity of the Amorphophallus native to the Meratus Mountains, South Kalimantan, Indonesia by $r b c \mathrm{~L}$ cpDNA marker, (ii) determine the genetic relationships or phylogenetic position of this germplasm from the region with other Amorphophallus species included in GenBank database, and (iii) provide some recommendations on the conservation and utilization of this germplasm for local, regional, and national government, particularly in Indonesia.

\section{MATERIALS AND METHODS}

\section{Plant materials}

We have used a total of 80 samples of Amorphophallus, comprises six samples (including three species, namely $A$. paeoniifolius, $A$. muelleri, and A. borneensis) collected directly from the Meratus Mountains, South Kalimantan, Indonesia (Table 1), and 74 other species, obtained randomly from GenBank database (Table 2).

\section{DNA extraction, amplification, and sequencing}

Total genomic DNA was extracted from collected leaf samples using the plant genomic DNA extraction kit (Geneaid Biotech Ltd., Taiwan) following a manufacturer's protocol. The DNAs were quantified using a UV-VIS spectrophotometer (NanoVue, GE Healthcare, UK) and standardized on $1.0 \%(\mathrm{w} / \mathrm{v})$ agarose gels. The $r b c \mathrm{~L}$ gene was amplified and sequenced with primers $r b c \mathrm{~L}-\mathrm{F}$ (5'ATGTCACCACAAACAGAGACTAAAGC-3') and $r b c \mathrm{~L}-$ R (5'-GTAAAATCAAGT CCACCRCG-3') from Gholave et al. (2017). Amplifications were conducted using the SimpliAMP Thermocycler PCR (Applied Biosystem, USA). A $25 \mu \mathrm{L}$ reaction mix, composed of $22 \mu \mathrm{L}$ PCR mix (MyTaq HS Red Mix, Bioline, UK), $2.0 \mu \mathrm{L}(10 \mu \mathrm{M})$ primer forward and reverse, and $1 \mu \mathrm{L}(10 \times$ diluted containing ca. 10 ng DNA) template. The amplified DNA fragments were then separated by $2 \%$ agarose gel with a 1X TBE buffer solution, stained with a DNA dye (FluoroVue, SMOBiO Technolgy, Taiwan), and observed by UV transilluminator. The successful amplified DNA was then sent to 1st Base Ltd., Malaysia, for purification and sequencing bidirectionally using the Sanger method.
All sequences were deposited in GenBank with accession numbers shown in Table 1.

\section{Genetic diversity and phylogenetic analyses}

Sequences were analyzed, edited and assembled using the MEGA-X software (Kumar et al. 2018). The genetic diversity was determined using the nucleotide diversity index $(\pi)$ method (Nei and Li 1979). Meanwhile, the level of genetic diversity was referred to Nei (1987) category, where 0.1 to 0.4 is low, 0.5 to 0.7 is the medium, and 0.8 2.00 is high. For phylogenetic analysis, multiple sequence alignments of sequences were performed with Clustal Omega (Sievers \& Higgins 2018) and edited manually using a similar software used previously to obtain an unambiguous sequence alignment. Interspecific genetic divergences were calculated using Kimura 2-Parameter (K2) distances in MEGA-X following the instruction of the CBOL for distance calculations (Kumar et al. 2018). Three phylogenetic analyses, namely Maximum Likelihood (ML), Maximum Parsimony (MP), and Neighbor-Joining (NJ) were also carried out in MEGA-X. The bootstrap analysis with 1000 replicates was applied for evaluated the topological robustness of the phylogram (Lemey et al. 2009).

\section{RESULTS AND DISCUSSION}

\section{Results}

Amorphophallus has a different length of $r b c \mathrm{~L}$ sequences, recorded between 543-1491 bp (Table 3). In this case, the shortest nucleotide (543 bp) is shown by $A$. borneensis from the Meratus Mountains of South Kalimantan, Indonesia, whereas the longest by $A$. henryi (1491 bp). Following Table 3, the $r b c \mathrm{~L}$ sequence of Amorphophallus has many polymorphic sites (126 loci) and a level of nucleotide diversity (0.63). Furthermore, this sequence also has several genetic information, such as BIC (8904.75), AIC (7386.04), and $\ln L$ values (-3534.79), including Transition/Transversion bias value (2.06) and GC content $(42.91 \%)$. Table 4 presented several polymorphic sites (nucleotide position), specifically on Amorphophallus from the South Kalimantan, Indonesia. Following Table 4, there are 17 loci of polymorphic site, where substitution (particularly transversion) is the most case, and a remaining (smallest part) is deletion.

Phylogenetic analysis using three approaches (NJ, ML, and MP) revealed specific positions of Amorphophallus from South Kalimantan (Figures 1-3, red highlight). In general, the three analyses generated a relatively similar phylogenetic tree, where Amorphophallus from the region are grouped consistently within other germplasms deposited in GenBank. For example, two samples of Amorphophallus species, namely A. muelleri from South Kalimantan (MT818204 \& MT818205), are grouping and close relatedness with previous A. muelleri at GenBank (AF497087.1). Similarly, three samples of $A$. paeoniifolius (MT818202, MT818203, and MT818206) clustered with the same species (DQ012500.1; AF497091.1), also with others, such as $A$. pranii, A. koratensis, A. scaber, and A. opertus (Figures 1-3). 
Table 1. List of Amorphophallus samples collected from the Meratus Mountains, South Kalimantan, Indonesia.

\begin{tabular}{llcc}
\hline Species & Origin & $\begin{array}{c}\text { Nucleotide length } \\
\text { (bp) }\end{array}$ & $\begin{array}{c}\text { Accession } \\
\text { number }\end{array}$ \\
\hline A. paeoniifolius & Lower Bajuin, Tanah Laut, South Kalimantan & 606 & MT818202 \\
A. paeoniifolius & Upper Bajuin, Tanah Laut, South Kalimantan & 606 & MT818203 \\
A. paeoniifolius & Piani, Tapin, South Kalimantan & 606 & MT818204 \\
A. muelleri & Lower Bajuin, Tanah Laut, South Kalimantan & 606 & MT818205 \\
A. muelleri & Upper Bajuin, Tanah Laut, South Kalimantan & 606 & MT818206 \\
A. borneensis & Piani, Tapin, South Kalimantan & 543 & MT818211 \\
\hline
\end{tabular}

Table 2. List of Amorphophallus obtained from GenBank database and its length sequences of the $r b c \mathrm{~L}$

\begin{tabular}{|c|c|c|}
\hline Species & $\begin{array}{l}\text { Nucleotide } \\
\text { length (bp) }\end{array}$ & $\begin{array}{c}\text { Accession } \\
\text { number }\end{array}$ \\
\hline A. abyssinicus & 1454 & AF497060.1 \\
\hline A. amygdaloides & 1433 & DQ012482.1 \\
\hline A. angolensis & 1470 & AF497061.1 \\
\hline A. ankarana & 1455 & AF497062.1 \\
\hline A. baumannii & 1482 & AF497063.1 \\
\hline A. beccarii & 1488 & AF497064.1 \\
\hline A. borneensis & 1453 & DQ012484.1 \\
\hline A. brevispathus & 1458 & AF497065.1 \\
\hline A. bufo & 1381 & KT794021.1 \\
\hline A. canaliculatus & 1479 & AF497066.1 \\
\hline A. cirrifer & 1484 & AF497067.1 \\
\hline A. coaetaneus & 1450 & AF497068.1 \\
\hline A. commutatus & 1460 & AF497069.1 \\
\hline A. corrugatus & 1459 & AF497070.1 \\
\hline A. dactylifer & 1456 & DQ012485.1 \\
\hline A. declinatus & 1448 & DQ012486.1 \\
\hline A. decus-silvae & 1454 & AF497071.1 \\
\hline A. dracontiodes & 1460 & AF497072.1 \\
\hline A. eburneus & 1459 & AF497073.1 \\
\hline A. eichleri & 1460 & AF497074.1 \\
\hline A. galbra & 1458 & AF497075.1 \\
\hline A. glossophyllus & 1459 & DQ012489.1 \\
\hline A. henryi & 1491 & AF497076.1 \\
\hline A. hewitii & 1432 & DQ012490.1 \\
\hline A. hirsutus & 1482 & AF497077.1 \\
\hline A. hirtus & 1458 & AF497078.1 \\
\hline A. hohenackeri & 1430 & DQ012491.1 \\
\hline A. hottae & 1391 & AM905785.1 \\
\hline A. johnsonii & 1459 & DQ012494.1 \\
\hline A. konjac & 1460 & AF497080.1 \\
\hline A. konkanensis & 1454 & DQ012495.1 \\
\hline A. koratensis & 1363 & KT794052.1 \\
\hline A. krausei & 1478 & AF497081.1 \\
\hline A. lambii & 1473 & AF497082.1 \\
\hline A. lanuginosus & 1451 & DQ012496.1 \\
\hline A. laoticus & 1458 & DQ012497.1 \\
\hline A. lewallei & 1486 & AF497083.1 \\
\hline A. longiconnectivus & 1454 & DQ012498.1 \\
\hline A. longituberosus & 1466 & AF497084.1 \\
\hline A. margaritifer & 1480 & AF497085.1 \\
\hline A. maxwellii & 1458 & AF497086.1 \\
\hline A. mossambicensis & 1448 & DQ012499.1 \\
\hline A. muelleri & 1441 & AF497087.1 \\
\hline A. napalensis & 1460 & AF497088.1 \\
\hline
\end{tabular}

\begin{tabular}{lll} 
A. napiger & 1488 & AF497089.1 \\
A. obscurus & 1364 & KT794063.2 \\
A. ochroleucus & 1472 & AF497090.1 \\
A. opertus & 1381 & KT794066.1 \\
A. paeoniifolius & 1479 & AF497091.1 \\
A. paeoniifolius var. bangkokensis & 1439 & DQ012500.1 \\
A. palawanensis & 1455 & AF497092.1 \\
A. pendulus & 1459 & DQ012501.1 \\
A. pingbianensis & 1476 & AF497093.1 \\
A. pranii & 1381 & KT794071.1 \\
A. pusillus & 1448 & AF497094.1 \\
A. pygmaeus & 1460 & AF497095.1 \\
A. rhizomatosus & 1482 & AF497096.1 \\
A. rivieri & 1347 & AJ005630.1 \\
A. rostratus & 1381 & KT794077.1 \\
A. sagittarius & 1463 & AF497097.1 \\
A. salmoneus & 1434 & DQ012502.1 \\
A. scaber & 1381 & KT794080.1 \\
A. scutatus & 1456 & DQ012503.1 \\
A. serrulatus & 1381 & KT794082.1 \\
A. smithsonianus & 1482 & AF497098.1 \\
A. sumawongii & 1487 & AF497099.1 \\
A. symonianus & 1472 & AF497100.1 \\
A. terrestris & 1344 & KT794091.1 \\
A. thaiensis & 1448 & DQ012504.1 \\
A. tinekeae & 1427 & DQ012505.1 \\
A. titanum & 1466 & AF497102.1 \\
A. variabilis & 1476 & AF497103.1 \\
A. yunnanensis & 1448 & AF497104.1 \\
A. zenkeri & 1460 & AF497105.1 \\
\hline & & \\
\hline
\end{tabular}

Table 3. Genetic information for the $r b c \mathrm{~L}$ region of Amorphophallus germplasm used in the study ${ }^{1}$.

\begin{tabular}{ll}
\hline Parameter & $\boldsymbol{r b c \mathbf { L }}$ \\
\hline Range of sequence length (bp) & $543-1491$ \\
Number of polymorphic sites $(S)$ & 126 \\
Bayesian Information Criterion (BIC) & 8904.75 \\
Akaike Information Criterion (AICc) & 7386.04 \\
Maximum Likelihood Value (lnL) & -3534.79 \\
Transition/Transversion (Ti/Tv) bias value $(R)$ & 2.06 \\
GC content $(\%)$ & 42.91 \\
Nucleotide diversity $(\pi \%)$ & 0.63 \\
\hline Note: ${ }^{1}$ Based on Kimura 2-parameter model.
\end{tabular}


Table 4. Polymorphic information for the $r b c \mathrm{~L}$ region of Amorphophallus from South Kalimantan, Indonesia.

\begin{tabular}{|c|c|c|c|c|c|c|c|}
\hline \multirow[b]{2}{*}{$\begin{array}{l}\text { Nucleotide } \\
\text { position }\end{array}$} & \multirow[b]{2}{*}{ Consensus } & \multicolumn{6}{|c|}{ Species/GenBank accession number } \\
\hline & & $\begin{array}{c}\text { A. paeoniifolius } \\
\text { var. Sylvestris } \\
\text { (MT818202) }\end{array}$ & $\begin{array}{c}\text { A.paeoniifolius } \\
\text { var. sylvestris } \\
\text { (MT818203) }\end{array}$ & $\begin{array}{l}\text { A. muelleri } \\
\text { (MT818204) }\end{array}$ & $\begin{array}{l}\text { A. muelleri } \\
\text { (MT818205) }\end{array}$ & $\begin{array}{l}\text { A. paeoniifolius } \\
\text { var. hortensis } \\
\text { (MT818206) }\end{array}$ & $\begin{array}{c}\text { A. borneensis } \\
\text { (MT818211) }\end{array}$ \\
\hline $43^{\mathrm{a}}$ & $\mathrm{T}$ & . & . & & . & . & $\mathrm{C}$ \\
\hline $86^{\mathrm{a}}$ & $\mathrm{T}$ & . & . & $\mathrm{G}$ & $\mathrm{G}$ & . & . \\
\hline $155^{\mathrm{a}}$ & $\mathrm{T}$ & . & . & . & . & . & $\mathrm{C}$ \\
\hline $164^{\mathrm{a}}$ & A & . & . & . & . & . & G \\
\hline $191^{\mathrm{a}}$ & $\mathrm{C}$ & $\mathrm{T}$ & $\mathrm{T}$ & $\mathrm{T}$ & $\mathrm{T}$ & $\mathrm{T}$ & $\mathrm{T}$ \\
\hline $254^{\mathrm{a}}$ & A & . & . & & . & . & $\mathrm{G}$ \\
\hline $266^{\mathrm{a}}$ & $\mathrm{C}$ & . & . & $\mathrm{T}$ & $\mathrm{T}$ & . & . \\
\hline $270^{\mathrm{ab}}$ & $\mathrm{G}$ & $\mathrm{T}$ & $\mathrm{T}$ & . & . & $\mathrm{T}$ & $\mathrm{C}$ \\
\hline $281^{\mathrm{a}}$ & $\mathrm{G}$ & A & A & . & . & A & . \\
\hline $341^{\mathrm{a}}$ & $\mathrm{T}$ & . & . & $\mathrm{C}$ & $\mathrm{C}$ & . & . \\
\hline $470^{\mathrm{a}}$ & $\mathrm{C}$ & $\mathrm{T}$ & $\dot{T}$ & . & . & $\mathrm{T}$ & . \\
\hline $497^{a}$ & $\mathrm{G}$ & . & . & $\dot{A}$ & A & . & . \\
\hline $560^{\mathrm{a}}$ & $\mathrm{C}$ & . & . & $\mathrm{T}$ & $\mathrm{T}$ & . & . \\
\hline $571^{\mathrm{a}}$ & $\mathrm{G}$ & . & . & . & . & . & $\mathrm{T}$ \\
\hline $596^{\mathrm{bc}}$ & $\mathrm{T}$ & . & A & . & . & . & - \\
\hline $598^{\mathrm{ac}}$ & A & $\mathrm{G}$ & $\mathrm{G}$ & $\mathrm{G}$ & $\mathrm{G}$ & . & - \\
\hline $605^{\mathrm{ac}}$ & $\mathrm{C}$ & $\mathrm{A}$ & $\mathrm{A}$ & $\mathrm{A}$ & $\mathrm{A}$ & $\mathrm{A}$ & - \\
\hline
\end{tabular}

Note: a: transversion, b: transition, c: deletion

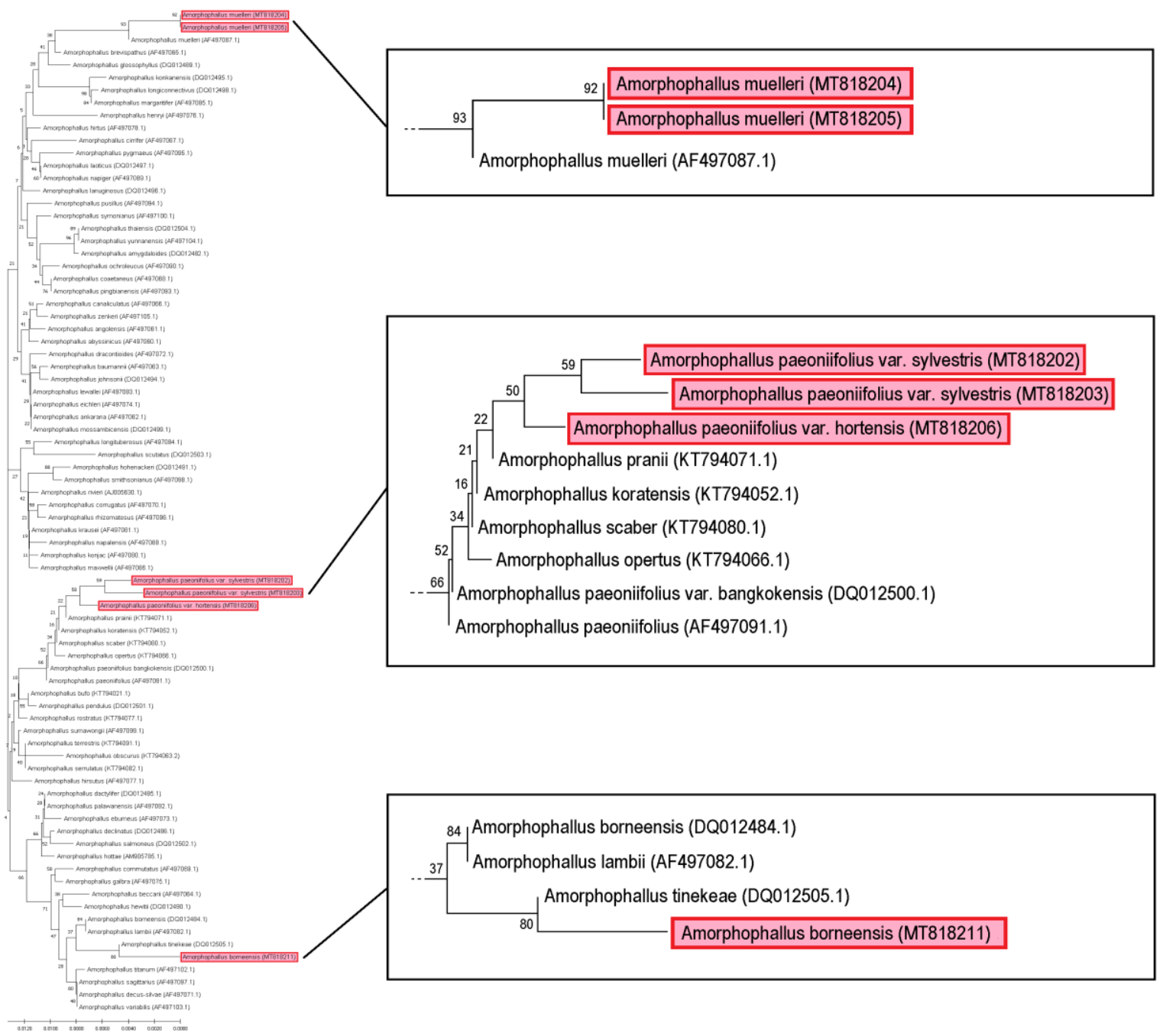

Figure 1. Phylogenetic position of Amorphophallus native to the Meratus Mountains of South Kalimantan, Indonesia (red highlight) based on Neighbor-Joining (NJ). The numbers above branches indicate bootstrap values inferred from 1000 replicates 

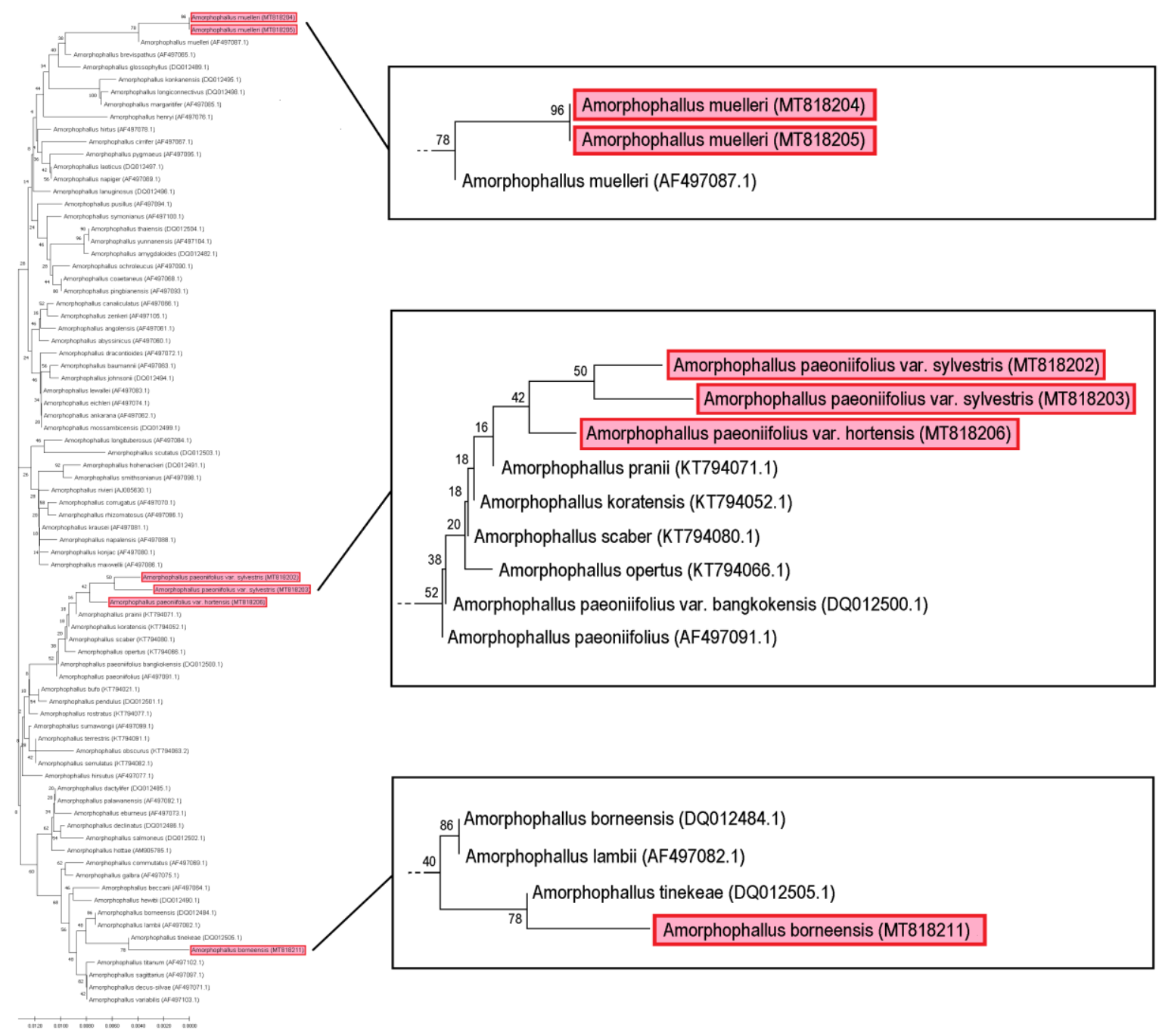

Figure 2. Phylogenetic position of Amorphophallus native to the Meratus Mountains of South Kalimantan, Indonesia (red highlight) based on Maximum Likelihood (ML). The numbers above branches indicate bootstrap values inferred from 1000 replicates

Interestingly, $A$. borneensis (MT818211), in this case, although it has a close relationship with $A$. Tinekeae (DQ012505.1) in NJ and ML analyses, MP have generated and joined this species with a similar A. Borneensis (DQ012484.1). However, a bootstrap analysis showed the lowest value (only 1\%) for the last approach (Figure 3), so it is not significant. Moreover, phylogenetic trees generated by $\mathrm{NJ}$ and ML have a bootstrap significance of $80 \%$ and $78 \%$, respectively (Figure 1 and 2).

\section{Discussion}

In this study, Amorphophallus has a moderate level of diversity, $p=0.63$ (Table 3). According to Govindaraj et al. (2015), genetic diversity is one factor in forming a baseline population for natural selection and the evolutionary process. In other words, it has a fundamental role in the future evolutionary trajectory or a prerequisite for future adaptive change of a species. Hence, genetic diversity has profound implications for species conservation and breeding (Lloyd et al. 2016). In conservation practices, understanding genetic diversity is essential in increasing effectiveness and efficiency, especially for rare species. Because some aspects of conservation biology, such as loss of genetic diversity, only addressed by detailed population genetic studies (Luan et al. 2006).

For plant breeding, genetic diversity becomes more urgent in the context of climate change (Govindaraj et al. 2015). Plant breeders utilize this aspect in plant genetic resources to develop new and improved cultivars with desirable traits, both associated with different biotic and abiotic stress tolerance and farmer-preferred (Swarup et al. 2021). It is also fundamental in generating many essential agricultural phenomena, like heterosis and transgressive segregation. Diverse lines are required for defect correction of commercial varieties and the development of new ones. Thus, identification of various cultivars (if available), creation of diversity (if not exist or limited), and their subsequent utilization are the main objectives of the crop improvement program (Bhandari et al. 2017). 


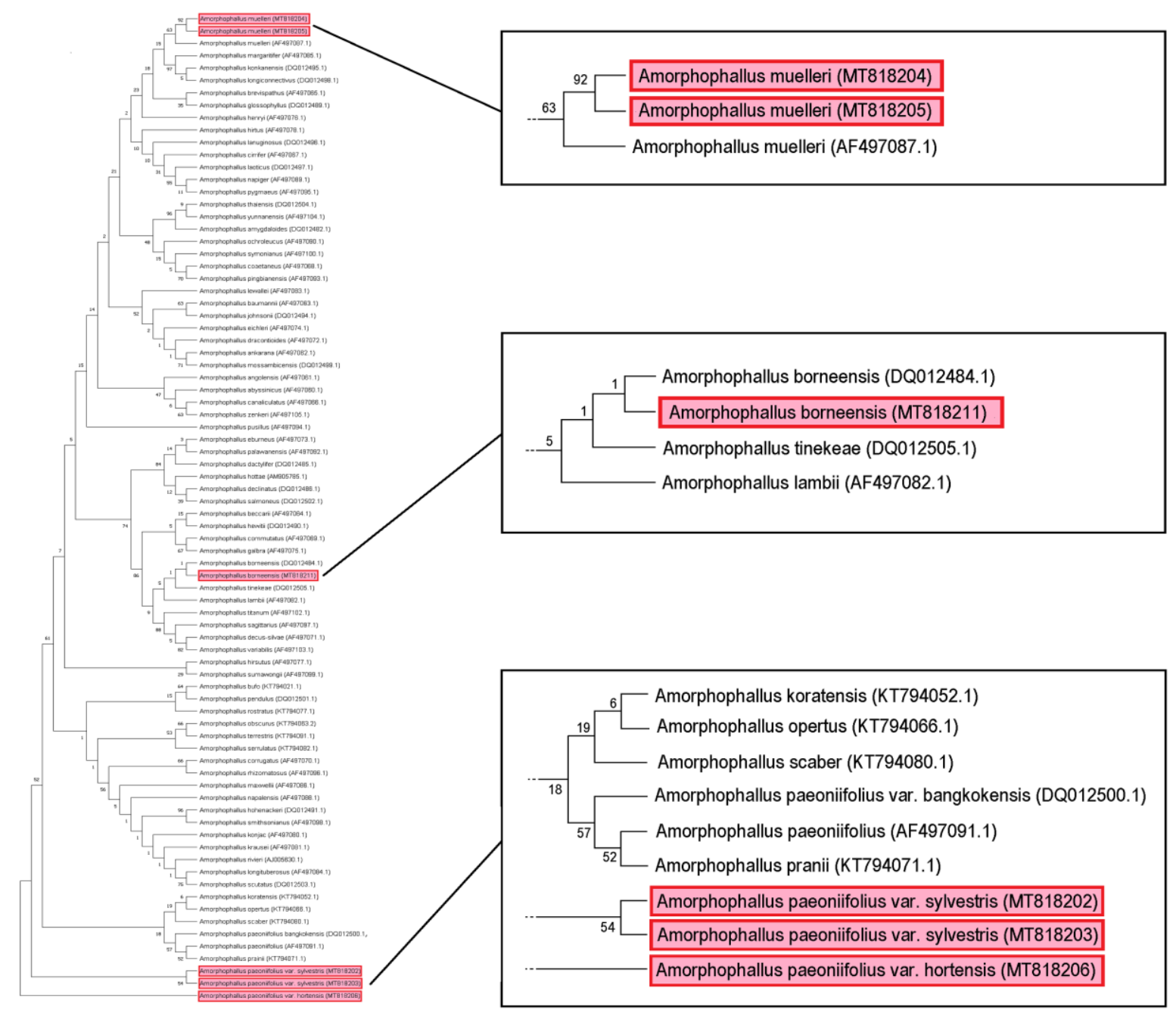

Figure 3. Phylogenetic position of Amorphophallus native to the Meratus Mountains of South Kalimantan, Indonesia (red highlight) based on Maximum Parsimony (MP). The numbers above branches indicate bootstrap values inferred from 1000 replicates

Compared to other studies with similar germplasm, there are differences in the value of genetic diversity. Amorphophallus in the study has a higher genetic diversity than reported by, for example, Gao et al. (2017a) in wild $A$. paeoniifolius population from Western China $(\mathrm{p}=0.23$ 0.36 ) but lower than similar germplasm in Asia with $\mathrm{p}=$ 0.80 (Santoso et al. 2017). Referred to Gao et al. (2017a), these differences might be due to the continuous selection had reduced effective population size and increased genetic drift and hitchhiking during domestication. During this process, inbreeding and intensive selection, which narrow the germplasm genetic base, tend to reduce the genetic diversity (Gao et al. 2017a). Further, reduced genetic diversity has been shown to decrease disease resistance and resilience to environmental disturbance and extreme conditions (Lloyd et al. 2016).

According to Lloyd et al. (2016), only as present-day populations need a high genetic diversity to rapidly adapt, future generations will need equally as much genetic diversity to adapt to future changes. Although the genetic diversity is currently high, the rapid rate of evolutionary change could outpace the rate of adaptation of this species. Consequently, future studies are necessary to understand how the loss of genetic diversity will impact the ability of future generations to continue to cope with environmental change in the population (Lloyd et al. 2016). It is because the low level of diversity may result from a founder effect, genetic isolation, population decline, or natural selection (Gao et al. 2017b).

Molecularly, the level of genetic diversity is affected by polymorphic or mutation events. In this case, the $r b c \mathrm{~L}$ sequence of this germplasm has generated many polymorphic sites $(126$ loci $)$ with a Transition /Transversion (Ti/Tv) bias value is recorded of 2.06 (Table 3). It means that transition is dominant to transversion and other mutations. Some researchers claim that the transition is more frequently encounter in sequences than transversions, as it can provide easy tolerance from selection pressure (Aloqalaa et al. 2019). In other words, a pattern in which nucleotide transitions are favored several times over transversions is commonly in molecular evolution (Stoltzfus and Norris 2015). It is due to the 
biased mutational processes within plant genomes, e.g., cytosine deamination (Lewis et al. 2016). In Amorphophallus and others, this case might be a loss of evolutionary potential (Gao et al. 2017a).

Information on the phylogenetic relationship is also urgent and has implications for species conservation and breeding (Flint-Garcia 2013). In this study, Amorphophallus revealed complex genetic relationships (Figure 1-3). Specifically, for native germplasm from South Kalimantan, Indonesia, is grouping with similar species in GenBank (Figure 1-3, red highlight). According to Fernández-García (2017), phylogenetic studies can apply in inferring species and their evolutionary history, including helping analyze species delimitation, gene flow, and genetic differentiation. Furthermore, the use of phylogenetic relationship is of current interest given its objective metrics for conservation in the past evolution history, the present genetic status of species, and management for future ones (Fernández-García 2017).

In-plant breeding program, information on this relationship can use in predicting the genetic diversity of the offspring when individuals cross (Acquaah 2012). Conceptually, crossing individuals with distant relationships, the offspring may have high genetic diversity. Conversely, if the individual is a closely related cross, then the genetic is low (Acquaah 2012, TurnerHissong et al. 2020). Hence, crossing the parent with a close relationship tends to avoid, due to the inbreeding, except in developing a new homozygous or pure-line hybrid (de Los Reyes 2019).

In conclusion, while Amorphophallus has a moderate level of genetic diversity, this germplasm revealed complex genetic relationships. Thus, this information is valuable in supporting the conservation and breeding programs of this germplasm, both locally and globally.

\section{ACKNOWLEDGEMENTS}

Thank you very much to Nico and fellow students who are members of the "Molecular Biology" Study Group, Biology Study Program of Faculty of Mathematics and Natural Sciences, Universitas Lambung Mangkurat, Banjarbaru, Indonesia for helping with the sample collection. We would also like to thank the Director of the Agricultural Quarantine Agency (Class I) Banjarmasin, South Kalimantan, who helped with the PCR analysis.

\section{REFERENCES}

Acquaah G. 2012. Principles of Plant Genetics and Breeding: Second Edition. Wiley-Blackwell, Oxford, UK.

Aloqalaa DA, Kowalski DR, Bła P, Wnetrzak M. 2019. In: Maria ED, Fred A, Gamboa $\mathrm{H}$. The impact of the transversion/transition ratio on the optimal genetic code graph partition; 12th Int Conf Bioinforma Model Methods Algorithms. Prague, Czech Republic, 22-24 February 2019. DOI: $10.5220 / 0007381000550065$.

Claudel C, Buerki S, Chatrou LW, Antonelli A, Alvarez N, Hetterscheid W. 2017. Large-scale phylogenetic analysis of Amorphophallus (Araceae) derived from nuclear and plastid sequences reveals new subgeneric delineation. Bot $\mathrm{J}$ Linn Soc 184: 32-45. DOI: 10.1093/botlinnean/box013 de Los Reyes BG. 2019. Genomic and epigenomic bases of transgressive segregation - New breeding paradigm for novel plant phenotypes. Plant Sci 288 (110213): 1-10. DOI: 10.1016/j.plantsci.2019.110213.

Dey YN, Ota S, Srikanth N, Jamal M, Wanjari M. 2012. A phytopharmacological review on an important medicinal plantAmorphophallus paeoniifolius. Ayu 33 (1): 27-32. DOI: 10.4103/0974-8520.100303.

Dong W, Cheng T, Li C, Xu C, Long P, Chen C, Zhou S. 2014. Discriminating plants using the DNA barcode rbcLb: An appraisal based on a large data set. Mol Ecol Resour 14 (2): 336-343. DOI: 10.1111/1755-0998.12185.

Fernández-García JL. 2017. Phylogenetics for wildlife conservation. In: Abdurakhmonov IY (eds). Phylogenetics. IntechOpen, London, UK.

Flint-Garcia SA. 2013. Genetics and consequences of crop domestication. J Agric Food Chem 2013: 1-36. DOI: 10.1021/jf305511d.

Gao Y, Yin S, Wu L, Dai D, Wang H, Liu C, Tang L. 2017a. Genetic diversity and structure of wild and cultivated Amorphophallus paeoniifolius populations in southwestern China as revealed by RADseq. Sci Rep 7 (14183): 1-10. DOI: 10.1038/s41598-017-14738-6.

Gao Y, Yin S, Yang H, Wu L, Yan Y. 2017b. Genetic diversity and phylogenetic relationships of seven Amorphophallus species in southwestern China revealed by chloroplast DNA sequences. Mitochondrial DNA Part A 29 (5): 679-686. DOI: 0.1080/24701394.2017.1350855

Gholave AR, Pawar KD, Yadav SR, Bapat VA, Jadhav JP. 2017. Reconstruction of molecular phylogeny of closely related Amorphophallus species of India using plastid DNA marker and fingerprinting approaches. Physiol Mol Biol Plants 23 (1): 155-167. DOI: 10.1007/s12298-016-0400-0.

Govindaraj M, Vetriventhan M, Srinivasan M. 2015. Importance of genetic diversity assessment in crop plants and its recent advances: an overview of its analytical perspectives. Genet Res Int 2015: 431487. DOI: $10.1155 / 2015 / 431487$

Grob GBJ, Gravendeel B, Eurlings MCM, Hetterscheid WLA. 2002. Phylogeny of the tribe Thomsonieae (Araceae) based on chloroplast matK and trnL intron sequences. Syst Bot 27 (3): 453-467..

Hollingsworth PM, Forrest LL, Spouge JL, Hajibabaei M, Ratnasingham S, van der Bank M, Chase MW, Cowan RS, Erickson DL, Fazekas AJ, Graham SW, James KE, Kim KJ, Kress WJ, Schneider H, van AlphenStahl J, Barrett SCH, van den Berg C, Bogarin D, Burgess KS, Cameron KM, Carine M, Chacón J, Clark A, Clarkson JJ, Conrad F, Devey DS, Ford CS, Hedderson TAJ, Hollingsworth ML, Husband BC, Kelly LJ, Kesanakurti PR, Kim JS, Kim YD, Lahaye R, Lee HL, Long DG, Madriñán S, Maurin O, Meusnier I, Newmaster SG, Park CK, Percy DM, Petersen G, Richardson JE, Salazar GA, Savolainen V, Seberg O, Wilkinson MJ, Yi DK, Little DP. 2009. A DNA barcode for land plants. Proc Natl Acad Sci USA 106 (31): 12794-12797. DOI: $10.1073 /$ pnas.0905845106.

Hollingsworth PM, Graham SW, Little DP. 2011. Choosing and using a plant DNA barcode. PLoS One 6 (5): e19254. DOI: 10.1371/journal.pone.0019254.

Keller I, Bensasson D, Nichols RA. 2007. Transition-transversion bias is not universal: A counter example from grasshopper pseudogenes. PLoS Genet 3 (2): e22. DOI: 10.1371/journal.pgen.0030022.

Korol AB. 2013. Recombination. In: Levin S (eds.). Encycl Biodivers Vol 6. Elsevier, Amsterdam.

Kumar S, Stecher G, Li M, Knyaz C, Tamura K. 2018. MEGA X: Molecular evolutionary genetics analysis across computing platforms. Mol Biol Evol 35 (6): 1547-1549. DOI: 10.1093/molbev/msy096.

Kurniawan A, Agus IP, Wibawa H, Adjie B. 2011. Species diversity of Amorphophallus (Araceae) in Bali and Lombok with attention to genetic study in A. paeoniifolius (Dennst.) Nicolson. Biodiversitas 12 (1): 7-11. DOI: $10.13057 /$ biodiv/d120102

Lemey P, Salemi M, Vandamme A-M. 2009. The phylogenetic handbook: A practical approach to phylogenetic analysis and hypothesis testing. Second Edi. Cambridge University Press, Cambridge, UK.

Lewis CA, Crayle J, Zhou S, Swanstrom R, Wolfenden R. 2016. Cytosine deamination and the precipitous decline of spontaneous mutation during Earth's history. Proc Natl Acad Sci USA 113 (29): 8194-8199. DOI: 10.1073/pnas.1607580113.

Lloyd MM, Makukhov AD, Pespeni MH. 2016. Loss of genetic diversity as a consequence of selection in response to high $p \mathrm{CO}_{2}$. Evol Appl 9 (9): 1124-1132. DOI: 10.1111/eva.12404.

Luan S, Chiang TY, Gong X. 2006. High genetic diversity vs. low genetic differentiation in Nouelia insignis (Asteraceae), a narrowly distributed 
and endemic species in China, revealed by ISSR fingerprinting. Ann Bot 98 (3): 583-589. DOI: 10.1093/aob/mcl129.

Mekkerdchoo O, Borompichaichartkul C, Perrigo AL, Srzednicki G, Prakitchaiwattana C, Antonelli A. 2016. Tracing the evolution and economic potential of konjac glucomannan in Amorphophallus species (Araceae) using molecular phylogeny and RAPD markers. Phytotaxa 282 (2): 81-106. DOI:10.11646/phytotaxa.282.2.1.

Nei M, Li WH. 1979. Mathematical model for studying genetic variation in terms of restriction endonucleases. Proc Natl Acad Sci USA 76 (10): 5269-5273. DOI: $10.1073 /$ pnas.76.10.5269.

Nei M. 1987. Molecular evolutionary genetics. Columbia University Press, New York, USA.

Nikmah IA, Azrianingsih R, Wahyudi D. 2016. Genetic diversity of Porang populations (Amorphophallus muelleri Blume) in Central Java and West Java based on $L E A F Y$ second intron marker. J Trop Life Sci 6 (1): 23-27. DOI: 10.11594/jtls.06.01.05.

Ripley LS. 2013. Mutation. In: Maloy S, Hughes K (eds). Brenner's Encyclopedia of Genetics, $2^{\text {nd }}$ ed. Elsevier, Amsterdam.

Saeb ATM, Al-Naqeb D. 2016. The impact of evolutionary driving forces on human complex diseases: A population genetics approach. Scientifica (Cairo) 2016: 1-10. DOI: 10.1155/2016/2079704

Santosa E, Lian CL, Sugiyama N, Misra RS, Boonkorkaew P, Thanomchit K. 2017. Population structure of elephant foot yams (Amorphophallus paeoniifolius (Dennst.) Nicolson) in Asia. PLoS One 12 (6) e0180000. DOI: 10.1371/journal.pone.0180000.

Sedayu A, Eurlings MCM, Gravendeel B, Hetterscheid WLA. 2010. Morphological character evolution of Amorphophallus (Araceae) based on a combined phylogenetic analysis of $t r n \mathrm{~L}, r b c \mathrm{~L}$ and $L E A F Y$ second intron sequences. Bot Stud 51: 473-490.
Sievers F, Higgins DG. 2018. Clustal Omega for making accurate alignments of many protein sequences. Tools Protein Sci 27: 135-145. DOI: $10.1002 /$ pro. 3290.

Smarda P, Bures P, Horová L, Leitch IJ, Mucina L, Pacini E, Tichý L, Grulich V, Rotreklová O. 2014. Ecological and evolutionary significance of genomic GC content diversity in monocots. Proc Natl Acad Sci USA 2014: E4096-E4102. DOI: 10.1073/pnas.1321152111F

Stoltzfus A, Norris RW. 2015. On the causes of evolutionary transition: transversion bias. Mol Biol Evol 33 (3): 595-602. DOI: 10.1093/molbev/msv274

Swarup S, Cargill EJ, Crosby K, Flagel L, Kniskern J, Glenn KC. 2021. Genetic diversity is indispensable for plant breeding to improve crops. Crop Sci 61 (2): 839-852. DOI: 10.1002/csc2.20377.

Terentieva EI, Varlygina TI, Darman GF, Degtjareva GV, Efimov SV, Samigullin TH. 2020. Revision and distribution of Liparis species (Orchidaceae) in Amur region (Russia). Nat Conserv Res 5 (Supplement 1): 102-113. DOI: $10.24189 /$ ncr.2020.044.

Turner-Hissong SD, Mabry ME, Beissinger TM, Ross-Ibarra J, Pires JC. 2020. Evolutionary insights into plant breeding. Curr Opin Plant Biol 54: 93-100. DOI: 10.1016/j.pbi.2020.03.003

Wahyudi D, Azrianingsih R, Mastuti R. 2013. Genetic variability of porang populations (Amorphophallus muelleri) in West Java and Central Java based on trnL intron sequences. J Biodivers Environ Sci 3 (9): 31-41.

Zhong L, Liu E, Yang C, Diao Y, Harijati N, Liu J, Hu Z, Jin S. 2018. Gene cloning of a neutral ceramidase from the sphingolipid metabolic pathway based on transcriptome analysis of Amorphophallus $\begin{array}{llllll}\text { muelleri. PLoS One } 13 & \text { (3): 1-13. DOI: }\end{array}$ 10.1371/journal.pone.0194863. 